\title{
DAKWAH ANTARBUDAYA: PERUBAHAN SOSIAL BUDAYA PADA PROSES ISLAMISASI JAWA ABAD XV
}

\author{
Charolin Indah Roseta \\ STID Al-Hadid, Surabaya \\ ircharolin@gmail.com
}

\begin{abstract}
Abstrak: Fenomena dakwah antarbudaya dalam rangka perubahan sosial-budaya tidak semuanya menghasilkan cultural conflict sebagaimana umumnya terjadi. Walisongo adalah perintis jalan penyebaran Islam di tanah Jawa secara revolusioner pada abad XV. Bentuknya berupa perubahan pemikiran masyarakat Jawa yang politeis Hindu Buddha menjadi monoteis Islam Sufi dalam waktu yang relatif singkat namun tanpa menimbulkan gejolak sosial. Adapun fokus tulisan ini adalah bagaimana bentuk dan strategi perubahan sosial budaya dalam dakwah Walisongo angkatan $V$ di Jawa abad XV yang bertujuan untuk mendeskripsikan bentuk dan strategi perubahan sosial-budaya dalam misi Islamisasi yang dilakukannya. Dengan pendekatan historis antropologis ditemukan bahwa misi dakwah Walisongo merupakan jenis perubahan sosial terencana dengan tahapan yang tersistematis dan strategis karena memanfaatkan infrastruktur local wisdom Jawa. Kajian ini mendapati bahwa proses pengadopsian nilai Islam pada masyarakat Jawa tidak lepas dari peran agen perubah budaya yang dimotori oleh Sunan Ampel setelah mampu memanfaatkan momentum krisis sosial-politik di Majapahit kala itu. Sedari awal ia membidik kalangan keraton dan bangsawan Jawa untuk melakukan "kaderisasi agen" dakwah. Strategi umumnya adalah dengan melakukan beberapa modifikasi pada berbagai sektor kehidupan masyarakat Jawa seperti pendidikan, ritual, bahasa, dan kesenian lokal menjadi lebih bernapaskan Islam.

Kata Kunci: Dakwah Antarbudaya, Perubahan Sosial, Walisongo
\end{abstract}

Intercultural Da'wah: Sociocultural Changes to the Islamization Proccess of Java in the 15th Century. Abstract: Intercultural da'wah phenomena in terms of sociocultural changes does not all generate cultural conflicts as it generally happens. Walisongo was a revolutionary pioneer on propagating Islam in Java in the 15th century. It changed polytheistic Hindu Buddhist thinking among Javanese society into Sufi Islamic monotheism in a relatively short period without causing any social conflict. This paper focuses on the form and strategy of sociocultural change of the 5th generation Walisongo's da'wah, aiming to describe the form and strategy of sociocultural change in their Islamic mission. With historical and anthropological approaches, it discovers that Walisongo's da'wah mission is a kind of well-planned social change with systematic and strategic stages, utilizing the infrastructure of Javanese local wisdom. It discovers that the process of adopting Islamic values could not be separated from the role of the agents of change led by Sunan Ampel after taking advantage of sociopolitical crisis in Majapahit. He earlier targeted Javanese royals and noblemen to form cadres of da'wah agents. His common strategy was to do some modifications on various life sectors such as education, ritual, language, and local art to have more Islamic values.

Key words: Intercultural da'wah, Sociocultural change, Walisongo 


\section{Pendahuluan}

Kajian tentang dakwah dan perubahan sosial saat ini masih belum banyak dikembangkan khususnya di Indonesia. Padahal menurut Amrullah dakwah yang dilakukan Nabi Muhammad saw. berorientasi pada perubahan sosial di masyarakat Arab. ${ }^{1}$ Dalam hal ini sudah menjadi pemahaman bersama bahwa Indonesia adalah negara yang majemuk dengan ribuan suku bangsa yang tersebar dari Sabang sampai Merauke, sehingga dakwah yang berparadigma perubahan sosial dalam konteks multikultural adalah suatu keniscayaan. Secara penerapan dakwah, proses perubahan sosial pada asumsi mad'uw yang majemuk (heterogen) tentunya berbeda dengan yang homogen. Menurut Ma'arif dalam menghadapi berbagai karakter objek dakwah, seorang dai idealnya memahami kondisi mad'uw, termasuk aspek keberagamaannya. Hal ini akan berpengaruh pada perbedaan cara dakwah di tengah masyarakat yang memiliki corak heterogen. ${ }^{2}$ Hal ini diperkuat dengan pendapat Nawawi dalam penelitiannya yang menawarkan suatu bentuk dakwah yang berorientasi pada perbaikan masyarakat idealnya mendasarkan pada asumsi budaya setempat. ${ }^{3}$ Dakwah dalam rangka perbaikan atau pembangunan masyarakat yang tidak mengindahkan nilai dan norma budaya maka akan sering berakhir dengan konflik dan penolakan. Hal tersebut dikarenakan adanya

\footnotetext{
1 Achmad Amrullah, Dakwah Islam Dan Perubahan Sosial, (Yogyakarta: Bidang Penerbitan PLP2M, 1985), 18.

2 Bambang S. Ma'arif dalam Yuliatun Tajuddin, "Walisongo dalam Strategi Komunikasi Dakwah," ADDIN, Vol. 8 No. 2 (2014). 376.

3 Nawawi, "Dakwah dalam Masyarakat Multikultural," Jurnal Komunika Vol. 6 No. 1 (2012), 9

4 Jacobus Ranjabar, Perubahan Sosial: Teori-teori dan Proses Perubahan Sosial serta Teori Pembangunan, (Bandung: Alfabeta, 2017), 61.
}

anggapan bahwa proyek pembangunan tersebut dapat mengganggu adat istiadat dan kebiasaan masyarakat setempat. Adapun Ranjabar dalam bukunya tentang perubahan sosial mengasumsikan bahwa setiap bangsa mempunyai kebudayaan, dan masing-masing mempunyai nilai norma yang berbeda satu dengan yang lain. Menurutnya jika suatu norma dari kelompok sosial tertentu diterapkan pada kelompok lain, maka akan memicu terjadinya culture conflict dan pertentangan norma. ${ }^{4}$ Pun demikian, jika pelaksanaan dakwahnya seorang dai hanya berfokus pada pembentukan norma perilaku islami mad'uw $^{\prime}$ tanpa mengindahkan adat kebiasaan setempat maka bukan tidak mungkin proses dakwah akan mengalami hambatan dan bahkan kegagalan sehingga dakwah berparadigma perubahan sosial hendaknya memperhatikan adat dan kebiasaan mad'uw-nya.

Dewasa ini terdapat fenomena tantangan dan hambatan kultural terhadap syiar Islam yang berorientasi pada perubahan dan perbaikan masyarakat yaitu penolakan dakwah karena kuatnya hegemoni budaya suku-suku di Indonesia. ${ }^{5} \mathrm{Hal}$ ini diperparah dengan munculnya bentuk dakwah yang cenderung memaksa dan menekankan pada formalitas Arab tanpa memperhatikan local wisdom setempat seperti kasus dibakarnya Ponpes Syiah di Sampang, ${ }^{6}$ konflik

\footnotetext{
5 Salah satunya adalah upaya dakwah dalam rangka mengislamkan masyarakat adat Baduy mendapat berbagai tantangan termasuk penolakan dan bahkan pengusiran adat hingga memecah komunitas ini menjadi tiga yaitu Tangtu, Pendamping, dan Dangka seperti yang dijelaskan dalam penelitian Kiki Muhammad Hakiki, "Keislaman Suku Baduy Banten," Jurnal Refleksi, Vol 14. No. 1 (2015), 8-12.

6 Rosidi, "Dakwah Multikultural di Indonesia: Studi Pemikiran dan Gerakan Dakwah Abdurrahman
} 
masyarakat dengan Jamaah Ahmadiyah hingga munculnya gerakan dakwah harakah yang melakukan pengeboman dan aksi kekerasan terhadap umat agama lain dengan tuntutan perubahan sosial secara total. ${ }^{7}$ Dampak terburuknya adalah ancaman dari berhentinya dakwah itu sendiri mengingat penolakan kultural tersebut mengartikan bahwa upaya dai dalam menyebarluaskan nilai dan ajaran Islam masih dipandang belum memiliki signifikansi kebermanfaatan terhadap kehidupan mad'uw. Selain itu penolakan adat juga dapat mendatangkan konflik dan perpecahan umat yang berpotensi mengancam semangat persatuan bangsa. Oleh karenanya, aktivitas dakwah yang dilakukan umat Islam idealnya mengarah pada upaya pembangunan dan perbaikan masyarakat dan bukan justru sebaliknya, seperti konflik sosial, perpecahan umat, dan bahkan kerusakan. Tidak semua aktivitas dakwah mengalami kendala cultural conflict atau dilakukan dengan jalan paksaan dan kekerasan saat dibenturkan dengan perbedaan budaya dengan mad'uw. Hal ini ditunjukkan dengan adanya fakta bahwa syiar Islam yang dilakukan oleh walisongo khususnya angkatan $\mathrm{V}$ di Pulau Jawa lebih banyak menggunakan jalan damai tanpa kekerasan, penuh toleransi dengan adat tradisi setempat yang berorientasi pada cultural exchange dan bukan paksaan bahkan kekerasan.

Adapun Tajuddin dalam penelitiannya menyatakan bahwa komunikasi dakwah yang dilakukan Walisongo tidak hanya

Wahid." Jurnal Analisis: Jurnal Studi Keislaman, Vol. 13 No. 2 (2013), 482

7 Muhammad Hizbullah, "Dakwah Harakah, Radikalisme, dan Tantangannya di Indonesia," Misykat Al-Anwar Jurnal Kajian Islam dan Masyarakat, Vol. 29 No. 2 (2018), 4. berorientasi mengajak saja, namun juga berbentuk mengomunikasikan kebiasaan baru yang bersinergi dengan tradisi asli. ${ }^{8}$ Menurutnya secara spesifik, dakwah Walisongo berorientasi pada pengelolaan serta pengembangan suatu masyarakat termasuk budayanya. Oleh karena terjadi perubahan mendasar dalam tradisi lama hingga terbentuk peradaban Islam Jawa dengan waktu yang relatif singkat, maka jenis dakwah Walisongo merupakan bentuk perubahan sosial secara revolusioner. ${ }^{9}$ Senada dengan hal ini, Abdullah menyebutnya sebagai revolusi sosial-agama pada masyarakat Hindu Jawa sehingga menghasilkan perubahan pada unsur-unsur kebudayaannya. Walisongo telah mengubah cara pandang masyarakat Jawa yang politeis Hindu Buddha dengan ajaran Islam yang monoteis. Cara yang dilakukan adalah dengan memanfaatkan local wisdom yang salah satunya adalah wayang yang saat itu sudah menjadi kesenian yang melembaga di sepanjang Pulau Jawa. Sistem pengajaran Islam dilakukan bertahap hingga menggeser praktik ritual Hindu Buddha dan berubah menjadi tahlil dan selamatan. Selain itu, hal yang paling mendasar adalah Walisongo telah berhasil mengubah watak khas masyarakat Majapahit yang berlandaskan pada nilai keagungan, kebesaran, kemuliaan, keunggulan, kemenangan, dan superioritas dalam setiap penaklukan, menjadi nilai-nilai Jawa muslim yang terkenal luhur, berbudi halus, bersikap santun dan penuh empati. ${ }^{10}$ Sedangkan terkait struktur sosial lama di Jawa saat itu yang lekat dengan sistem kasta sebagaimana tradisi Hindu secara perlahan

8 Yuliatun Tajuddin, "Walisongo dalam Strategi Komunikasi Dakwah," ADDIN, Vol. 8 No. 2 (2014), 388.

9 lbid., 72.

${ }^{10}$ Ibid., 442-446. 
direduksi dan diubah menjadi pola "gurusantri" lewat pendirian pesantren. Berdasarkan atas fenomena tersebut dapat dipahami bahwa strategi dakwah Walisongo nyatanya dapat menciptakan perubahan kebudayaan yang cukup signifikan dari tradisi Hindu-Buddha menjadi Islam tanpa menimbulkan gejolak sosial yang berarti. Lebih lanjut Purwadi menyatakan bahwa penyebaran Islam oleh para wali tergolong berhasil meskipun di beberapa daerah masih tetap menjalankan agama Hindu dan Buddha seperti tradisi nenek moyang. ${ }^{11}$

Fase dakwah Walisongo memiliki sejarah panjang dan tersebar hampir ke seluruh pelosok Indonesia pada masanya. Pembahasan dakwah Walisongo ini akan difokuskan pada angkatan $\mathrm{V}$ yang faktanya memiliki signifikansi perubahan sosialbudaya yang besar dan menjadi tonggak penyebaran Islam khususnya di Pulau Jawa dan di Indonesia pada umumnya. Adapun fokus kajian dalam tulisan ini adalah terkait dengan bagaimana bentuk dan strategi perubahan sosial budaya dalam dakwah Walisongo angkatan $V$ di tanah Jawa abad $X V$ ?, yang bertujuan untuk mendeskripsikan bentuk dan strategi perubahan sosialbudaya dalam misi islamisasi. Metodologi yang digunakan dalam studi ini adalah kualitatif deskriptif dengan jenis penelitian pustaka khususnya historis antropologis karena mengkaji sejarah agama, di mana realitas agama dan praktik sosial akan dilihat

\footnotetext{
11 Purwadi, Dakwah Sunan Kalijaga: Penyebaran Agama Islam di Jawa Berbasis Kultural, (Yogyakarta: Pustaka Pelajar, 2007), 86.

12 Ali Sodikin, Antropologi Al-Quran: Model Dialektika Wahyu \& Budaya, (Yogyakarta: Ar-Ruzz Media, 2013), 25.

${ }^{13}$ Agus Sunyoto, Atlas Walisongo: Buku Pertama yang Mengungkap Walisongo sebagai Fakta Sejarah, (Depok: Pustama Iman, 2017).
}

secara bersama-sama dengan menggali peristiwa-peristiwa kunci berdasarkan sumber sejarah yang relevan. ${ }^{12}$ Adapun datadata sejarah dalam tulisan ini dipaparkan dan dikategorisasikan ke dalam tema-tema sentral perubahan sosial dengan mekanisme triangulasi dari tiga buku utama yaitu Atlas Walisongo: Buku Pertama yang Mengungkap Walisongo Sebagai Fakta Sejarah $^{13}$ sebagai sumber data utama, buku kedua berjudul Sejarah Lengkap Walisanga, dari Masa Kecil, Dewasa, Hingga Akhir Hayatnya ${ }^{14}$ serta buku lainnya menjelaskan kiprah dakwahnya secara umum yaitu Walisongo: Gelora Dakwah dan Jihad di Tanah Jawa (1404 - 1482). ${ }^{15}$

Kajian mengenai kiprah walisongo sudah banyak dilakukan baik dalam jurnal dan buku-buku ilmiah. Beberapa karya ilmiah banyak mengangkat tema dakwah yang dilakukan oleh Walisongo seperti Strategi Komunikasi Dakwah Walisongo ${ }^{16}$ oleh Yuliatun Tajuddin serta Strategi dan Metode Dakwah Walisongo, ${ }^{17}$ oleh Hatmansyah. Meskipun memiliki persamaan pada objek kajiannya, namun terdapat perbedaan cukup besar dengan karya Tajuddin yang lebih menitikberatkan pada aspek komunikasi yang digunakan Walisongo dalam dakwahnya. Adapun tulisan ini hendak mengembangkan pembahasan lebih luas pada usaha mereka untuk melakukan perubahan sosial-budaya. Pun demikian dengan karya jurnal kedua, meski tulisan ini

\footnotetext{
14 Masykur Arif, Sejarah Lengkap Wali Sanga, Dari Masa Kecil, Dewasa, Hingga Akhir Hayatnya, (Yogyakarta: Dipta, 2013).

15 Rachmad Abdullah, Walisongo: Gelora Dakwah dan Jihad di Tanah Jawa (1404-1482), (Bandung: Al-Wafi Publishing, 2017).

16 Yuliatun Tajuddin, "Walisongo dalam Strategi Komunikasi Dakwah," 368.

17 Hatmansyah, "Strategi dan Metode Dakwah Walisongo," Jurnal Al-Hiwar, Vol. 03 No. 05 (2015).
} 
memiliki irisan pembahasan dalam hal cara dakwah Walisongo, namun strategi-metode dakwah tersebut akan dianalisis dengan pendekatan teori perubahan sosial-budaya. Selain itu ada pula tulisan berjudul Dakwah Budaya Walisongo ${ }^{18}$ dan Strategi Kultural Walisongo $^{19}$ yang spesifik membahas tentang pendekatan kultural dalam dakwahnya. Namun pada tulisan ini pendekatan dakwah kultural yang dilakukan oleh Walisongo akan dikaji secara menyeluruh dan sistematis dalam tiap tahap perubahan budaya, baik terkait proses perubahannya, saluran serta media yang digunakan termasuk faktor pendorong dan penghambatnya yang dihadapi Walisongo sebagai agent of change. Dengan begitu barangkali bisa membuka wacana bahwa dakwah yang berorientasi pada perbaikan masyarakat tidak seharusnya dilakukan dengan cara-cara radikal seperti pengeboman atau aksi kekerasan lainnya yang dilakukan oknum-oknum yang mengatasnamakan Islam.

Adapun manfaat lain dari memahami pola dakwah yang dilakukan Walisongo ini adalah dapat memberi referensi tambahan terkait bentuk dan dinamika dakwah yang dilakukan di konteks perbedaan kultur namun tanpa menimbulkan pergolakan sosial yang berarti. Selain itu dapat membuka wacana sebagian kalangan bahwa orientasi dakwah apabila dikembangkan dalam bentuk misi perubahan sosial yang terencana akan dapat mencapai hasil maksimal yaitu perubahan kebudayaan itu sendiri. Khususnya saat dai

\footnotetext{
18 Muh Fatkhan, "Dakwah Budaya Walisongo: Aplikasi Metode Dakwah Walisongo di Era Multikultural," Aplikasia: Jurnal Aplikasi ilmu-ilmu Agama, Vol. 4 No. 2 (2003)

19 Suparjo, "Islam dan Budaya: Strategi Kultural Walisongo dalam Membangun Masyarakat Muslim Indonesia," Jurnal Komunika, Vol. 2 No. 2 (2008).
}

dihadapkan pada tantangan pemikiran dari mad'uw yang memiliki keragaman keyakinan dan kepercayaan nonmuslim seperti masyarakat adat yang masih banyak tersebar di pelosok Nusantara.

\section{Teori Perubahan Sosial Budaya}

Secara kebahasaan, perubahan sosial budaya berasal dari kata perubahan yang berarti menjadi lain (berbeda) dari semula atau bertukar (beralih, berganti) menjadi sesuatu yang lain. Sosial yang berarti berkenaan dengan masyarakat. Budaya berarti pikiran, akal budi, sesuatu yang sudah menjadi kebiasaan yang sudah sukar diubah. ${ }^{20}$ Sedangkan beberapa pengertian perubahan sosial menurut ahli yaitu Selo Soemardjan, perubahan sosial adalah segala perubahan-perubahan pada lembagalembaga kemasyarakatan di dalam suatu masyarakat yang berpengaruh pada sistem sosialnya, termasuk di dalamnya nilai-nilai, sikap dan pola perilaku di antara kelompokkelompok dalam masyarakat. Terkait dengan perubahan kebudayaan, Soekamto menyatakan bahwa kebudayaan dikatakan tata cara bertingkah laku manusia atas dasar konsep berpikir tertentu, yang terjadi pada saat manusia interaksi dan berkomunikasi seperti menyampaikan hasil pikirannya secara simbolis yang tidak diwariskan secara turun temurun. ${ }^{21}$ Berdasarkan atas asumsi bahasa dan pendapat ilmuan tersebut dapat diartikan bahwa perubahan sosial budaya adalah suatu kondisi peralihan bentuk budaya pada suatu masyarakat menjadi

\footnotetext{
$20 \mathrm{KBBI}$ online, diakses 21 September 2019. https://kbbi.web.id/.

${ }^{21}$ Kingsley Davis, dalam Soerjono Soekanto, Sosiologi Suatu Pengantar, Jakarta: PT. Raja Grafindo Persada, 2007, 266.
} 
bentuk lain baik dalam hal pergeseran nilai atau kebiasaan perilaku dan atau artefaknya.

Salah satu jenis perubahan sosial-budaya yang disoroti dalam tulisan ini adalah perubahan yang direncanakan (plannedchange) dan telah diperkirakan atau sengaja direncanakan terlebih dahulu oleh pihakpihak yang hendak mengadakan perubahan di dalam masyarakat (agent of change) atau disebut sebagai perubahan yang dikehendaki (intended-change). Dalam hal ini agen melakukan pengelolaan masyarakat dan mengubah pranata bahkan struktur sosialnya. Dalam proses melaksanakannya, para agen bertanggung jawab dan bahkan mungkin akan mengantisipasi kemungkinan perubahan-perubahan lain dari lembaga sosial di masyarakat. ${ }^{22}$

Secara teoretis, proses perubahan dimulai dari mekanisme yang disebut sebagai disorganisasi (disintegrasi) yaitu suatu proses berpudarnya nilai-nilai dan normanorma dalam suatu masyarakat sebagai akibat dari adanya pergeseran atau perubahan yang terjadi pada lembagalembaga kemasyarakatan. Tahapan berikutnya adalah proses reorganisasi (reintegrasi) yang mengindikasikan adanya suatu proses pembentukan norma-norma dan nilai-nilai baru sebagai akibat dari penyesuaian atas adanya pergeseran dan atau perubahan pada pranata sosial suatu masyarakat. Adapun tahap reorganisasi dilaksanakan bilamana norma-norma dan nilai-nilai yang baru telah melembaga (institutionalized) dalam setiap diri anggota masyarakat. $^{23}$

\footnotetext{
${ }^{22}$ Selo Sumardjan dalam Soerjono Soekanto, Sosiologi Suatu Pengantar, (Jakarta: Raja Grafindo Persada, 2007), 272-273.

23 Soerjono Soekanto, Sosiologi Suatu Pengantar, (Jakarta: Raja Grafindo Persada, 2007), 293.
}

Dalam ilmu sosiologi, terdapat dua bentuk perubahan kebudayaan yaitu akulturasi dan asimilasi. Adapun akulturasi terjadi apabila suatu kelompok manusia dengan suatu kebudayaan tertentu berinteraksi dengan unsur-unsur suatu kebudayaan asing yang berbeda sehingga menyebabkan perubahan pada unsur-unsur kebudayaan sendiri, namun tanpa menyebabkan hilangnya watak dan kekhasan kebudayaan itu sendiri. ${ }^{24}$ Artinya jika terjadi pertemuan/hubungan antara suatu kebudayaan tertentu dengan kebudayaan lain, maka unsur-unsur budaya asing tersebut berangsur-angsur akan diterima dan kemudian diolah ke dalam kebudayaannya sendiri tanpa menyebabkan kehilangan ciri khas budaya asal. Terkait unsur kebudayaan asing yang mudah dan sulit berakulturasi, Soekamto menyebutkan beberapa hal yaitu unsur kebudayaan seperti kebendaan atau alat-peralatan yang bersifat mudah dipakai dan dirasakan sangat bermanfaat bagi masyarakat penerimanya maka akan mudah terakulturasi. Apalagi jika unsur tersebut terbukti membawa manfaat besar dan menjadi salah satu solusi bagi persoalan hidup masyarakat setempat. Sebaliknya unsur budaya asing yang menyangkut sistem kepercayaan seperti falsafah hidup, ideologi dan lain-lain atau unsur-unsur yang dipelajari pada taraf pertama sosialisasi akan sulit diterima apalagi jika unsur tersebut bertentangan dengan adat tradisi mereka. ${ }^{25}$

Adapun bentuk kedua adalah asimilasi yang merupakan suatu proses sosial sebagai perkembangan lebih lanjut dari mekanisme

24 Koentjaraningrat, Pengantar IImu Antropologi, (Jakarta: Rineka Cipta, 1990), 248.

25 Soekanto, Sosiologi Suatu Pengantar, 169. 
akulturasi. ${ }^{26}$ Secara singkat, proses asimilasi diorientasikan untuk mencapai tahap integrasi dan organisasi, pikiran dan tindakan yang ditandai dengan mengembangkan sikap-sikap yang sama antaranggota masyarakat, meskipun terkadang bersifat emosional dengan tujuan minimal dapat mencapai kesatuan sosial. Adapun Koentjaraningrat menyebutkan syarat suatu kondisi asimilatif yaitu pertama, jika terdapat hubungan interaksi antarkelompok manusia yang memiliki perbedaan kebudayaan. Kedua, interaksi tersebut terjadi secara langsung dan intensif untuk waktu yang lama dan orang perorangan sebagai warga kelompok tadi saling bergaul sehingga kebudayaankebudayaan dari kelompok manusia tersebut saling berubah dan masing-masing melakukan penyesuaian diri. ${ }^{27}$ Sedangkan menurut Soerjono Soekanto menyatakan bahwa pada konteks masyarakat tradisional yang masih terasing di Indonesia untuk mengadakan interaksi sosial yang asimilatif masih merupakan hal yang sulit dikarenakan warganya memiliki peluang yang minim untuk berinteraksi dengan masyarakat lain termasuk masyarakat kota. ${ }^{28}$ Namun jika terdapat kesempatan-kesempatan menjalin kerja sama di bidang ekonomi maka hal tersebut bisa menjadi faktor pendorong asimilasi. Selain itu juga diperlukan sikap menghargai serta toleransi terhadap orang asing dan kebudayaannya. Terlebih jika ditunjang sikap terbuka dari pihak yang berkuasa dalam masyarakat. Faktor pendorong berikutnya adanya perkawinan campuran (amalgamation), memiliki kesamaan unsur kebudayaan, serta menghadapi musuh bersama dari luar. ${ }^{29}$

26 Ibid., 74

27 Koentjaraningrat, Pengantar IImu Antropologi., 255.
Selain itu terdapat faktor lain yang dapat mendorong percepatan proses perubahan sosial budaya yaitu munculnya keinginankeinginan untuk maju yang melahirkan sikap toleransi serta menghargai hasil karya orang/kebudayaan lain. Hal ini biasanya ditunjang dengan sistem pendidikan formal yang maju dalam suatu masyarakat tertentu. Selain itu juga adanya asumsi komposisi penduduk yang heterogen, sistem lapisan masyarakat terbuka, serta faktor ketidakpuasan masyarakat terhadap bidangbidang kehidupan tertentu juga dapat menjadi salah satu pendorong perubahan sosial budaya, apalagi jika diperkuat dengan adanya pemahaman bahwa manusia harus senantiasa berusaha untuk memperbaiki hidupnya. Sedangkan media dan saluran perubahan untuk setiap kasus perubahan dapat berupa perdagangan, difusi, maupun misi agen tertentu, termasuk penjajahan.

Menurut Soekanto terdapat faktor internal penyebab perubahan sosial budaya yaitu adanya penemuan baru (inovasi), bertambah/berkurangnya penduduk, terjadi konflik kepentingan antar golongan atau terjadinya pemberontakan seperti bencana alam dan atau peperangan. Selain itu dari eksternal, adanya pengaruh masyarakat lain bisa menjadi faktor penyebab perubahan. Terkait dengan faktor penyebab terakhir ini Sukanto mengemukakan bahwa interaksi fisik intensif yang dilakukan oleh dua kebudayaan memungkinkan terjadinya pengaruh timbal balik. Artinya, masingmasing masyarakat saling menerima unsur budaya asing sekaligus saling memengaruhi satu sama lain. Namun, ada kemungkinan pengaruh itu hanya datang dari satu pihak saja jika hubungan tersebut terjadi lewat

\footnotetext{
28 Soekanto, Sosiologi Suatu Pengantar, 75.

29 Ibid., 76-77.
} 
saluran komunikasi massa, dari masyarakat pengguna alat-alat komunikasi tersebut. Di satu sisi, pihak lain hanya menerima pengaruh tanpa memiliki peluang untuk memberikan pengaruh balik.

\section{Kebudayaan Jawa Sebelum dan Sesudah Masuknya Islam}

Sejarah mencatat bahwa kebudayaan Jawa sebelum masuknya Islam memiliki falsafah hidup yang bersumber dari agama kuno bernama Kapitayan. Agama tersebut merupakan sistem hidup warisan dari nenek moyang Jawa. ${ }^{30}$ Hingga abad ke XV dasar nilai budaya Jawa lebih banyak dititikberatkan pada sinkretisme (pencampuran) ajaran Kapitayan yang identik dengan konsep mistis dengan HinduBuddha berasal dari India. ${ }^{31}$

Di sisi lain dalam hal kehidupan sosial, khususnya di bagian tengah dan timur Jawa berkembang nilai-nilai keagungan yang berasal dari kerajaan Majapahit yang menjadi standar hidup makmur yaitu mendapatkan kemenangan dengan mendasarkan pada ambisi yang besar berupa nilai-nilai keunggulan, kebesaran, superioritas, keagungan, kemuliaan atas kemenangan penaklukan oleh kerajaan Majapahit. ${ }^{32}$ Bentuk lain dari perwujudan nilai Jawa yang cenderung arogan salah satunya dapat dilihat pada fenomena kehidupan masyarakat di wilayah Sunan Gresik tinggal. Di daerah ini terdapat kesenjangan sosial yang cukup tinggi dengan demografi penduduk yang disusun atas dasar kelas sosial. Masyarakat dibagi ke

\footnotetext{
${ }^{30}$ Agus Sunyoto, Atlas Walisongo: Buku Pertama yang Mengungkap Walisongo Sebagai Fakta Sejarah, (Depok: Pustaka Iman, 2017), 13.

31 Ibid., 17.
}

dalam kelas sosial tinggi, tengah, dan rendah. Kelompok sosial pada strata rendah memiliki nasib yang malang karena cenderung tidak dapat menikmati hak-hak asasi manusia. Hal ini karena mereka dianggap tidak berguna dalam banyak bidang kehidupan lantaran kelas sosialnya yang rendah. ${ }^{33}$

Setelah masuknya Islam, masyarakat Jawa mengalami perubahan signifikan khususnya pada tataran moral yang jika sebelumnya dikenal arogan dan superior khas Majapahit berubah menjadi menjunjung tinggi sikap andhap ashor dan keharmonisan hidup. Adapun Agus Sunyoto dalam bukunya menyebutkan bahwa sebagaimana lazimnya nilai-nilai yang bersumber dari ajaran Islam, nilai-norma yang dikembangkan oleh Walisongo di era akhir Majapahit yang ditanamkan, ditegakkan atas dasar asas harmonisasi keselarasan. ${ }^{34}$ Beberapa nilai Islam yang ditanam Walisongo pada masyarakat Jawa merujuk pada nilai Islam sufistik seperti kesabaran (shabar), kesederhanaan (wara'), ngalah (tawakal), keikhlasan (ikhlas), lila atau kerelaan (ridha), andhap asor (tawadhu'), nrimo (qana'ah), keadilan ('adl), guyub dan rukun (ukhuwah). Selain itu juga diajarkan moralitas yang membuat manusia mampu mengendalikan batin dan hawa nafsu sehingga menekankan sikap rendah hati terhadap sesama dan tidak gemar cekcok. Alasan yang dikemukakan adalah bahwa dengan hawa nafsu dapat menjerumuskan manusia kepada jalan kesesatan. ${ }^{35}$ Adapun dalam referensi lain menyebutkan bahwa terdapat ajaran Walisongo tentang orientasi hidup manusia

\footnotetext{
32 lbid., 442-446.

33 Arif, Sejarah Lengkap Wali Sanga, 30

34 Sunyoto, Atlas Walisongo, 442-446.

35 Ibid.
} 
yaitu jika dapat menyesuaikan diri dengan lingkungan di sekitarnya atau bahkan dapat menembus sampai padanya, maka akan mecapai keberhasilan dalam hidup. ${ }^{36}$ Adapun kriteria keberhasilannya adalah ketentraman batin yang tenang yaitu kondisi slamet (selamat) baik di dunia maupun akhirat dan hanya dapat tercapai apabila manusia memiliki sikap batin yang tepat. Adapun variabel-variabel perubahan budaya di Jawa diuraikan sebagai berikut:

\section{1) Walisongo sebagai Agen perubahan}

Dalam beberapa buku yang menyatakan bahwa Walisongo adalah sebuah nama bagi dewan dakwah, perkumpulan ulama, dewan mubalig, majelis para wali yang bernaung dalam organisasi atau lembaga dakwah yang berjumlah sembilan orang dalam setiap angkatan. Para guru sufi ini awalnya datang ke Indonesia untuk berdagang namun sengaja menyebarkan ajaran tasawuf baik secara personal maupun kelompok khususnya di tanah Jawa. Maulana Malik Ibrahim (1404 - 1419 M) adalah pembawa gagasan sufistik ini sekaligus perintis dan pendiri "lembaga" Walisongo angkatan I untuk kemudian diteruskan oleh Sunan Ampel (1401 - 1481 M) atau Raden Rahmat yang menjadi leader di angkatan V. Dalam buku Atlas Walisongo menyebutkan bahwa pada tahun 1440 M Raden Rahmat, putra dari Ibrahim Asmarakandi datang ke Jawa bersama dengan saudaranya Ali Murtadho. Momen tersebut dikatakan sebagai awal dimulainya sistem dakwah Islam secara masif, sistematis, dan terorganisir. ${ }^{37}$ Secara umum tiap anggota Walisongo memiliki hubungan kedekatan satu sama lain, baik karena ada hubungan darah atau karena ikatan guru dan murid. Sunan tertua adalah Maulana Malik Ibrahim (wafat 1419 M) memiliki anak yaitu Sunan Ampel (1401 1481 M). Sunan Bonang (1465 - 1525 M) dan Sunan Drajad (1470 - 1522 M) adalah anak Sunan di Ampeldenta ini. Sunan Giri (1442 1506 M) adalah sepupunya karena dia merupakan keponakan ayahnya. Adapun Sunan Kalijaga (1460 - 1513 M) adalah sahabat sekaligus murid putra pertamanya, Sunan Bonang. Sedangkan Sunan Muria merupakan anak Sunan Kalijaga. Sunan Kudus (wafat $1550 \mathrm{M}$ ) merupakan murid Sunan Kalijaga. Sedangkan Sunan Gunung Jati $(1448-1568$ M) adalah sahabat para Sunan lain, kecuali Maulana Malik Ibrahim yang telah meninggal lebih dulu. ${ }^{38}$

Tabel 1 - Daftar Walisongo Berdasarkan Angkatan ${ }^{39}$

\begin{tabular}{lll}
\hline \multicolumn{1}{c}{ Angkatan I (1404-1421) } & \multicolumn{1}{c}{ Angkatan II (1421 - 1436) } & \multicolumn{1}{c}{ Angkatan III (1436-1463) } \\
\hline \hline 1. M. Malik Ibrahim & 1. Sunan Ampel & 1. Sunan Ampel \\
2. Maulana Ishaq & 2. Maulana Ishaq & 2. Maulana Ishaq \\
3. M. A. Jumadil Kubra & 3. M. A. Jumadil Kubra & 3. M.A. Jumadil Kubra \\
4. Muh. Al-Maghribi & 4. Muh. Al-Maghribi & 4. Muh. Al-Maghribi \\
5. M. Malik Israil & 5. M. Malik Israil & 5. Ja'far Shodiq \\
6. Muh. Ali Akbar & 6. Muh. Ali Akbar & 6. Syarif Hidayatullah \\
7. Maulana Hasanuddin & 7. Maulana Hasanuddin & 7. Maulana Hasanuddin \\
8. Maulana Aliyuddin & 8. Maulana Aliyuddin & 8. Maulana Aliyuddin
\end{tabular}

${ }^{36}$ Purwadi, Dakwah Sunan Kalijaga, 86.

37 Sunyoto, Atlas Walisongo, 399.

${ }^{38}$ Abdullah, Walisongo, 20 


\begin{tabular}{lll}
\hline \multicolumn{1}{c}{ Angkatan IV (1463-1466) } & \multicolumn{1}{c}{ Angkatan V (1466- 1478) } & \multicolumn{1}{c}{ Angkatan VI (1478 - ...M) } \\
\hline \hline 1. Sunan Ampel & 1. Sunan Giri & 1. Sunan Giri \\
2. Sunan Mbonang & 2. Sunan Ampel & 2. Sunan Ampel \\
3. A. Jumadil Kubra & 3. Sunan Mbonang & 3. Sunan Mbonang \\
4. Muh. Al-Maghribi & 4. Sunan Kudus & 4. Sunan Kudus \\
5. Ja'far Shodiq & 5. Sunan Gunung Jati & 5. Sunan Gunung Jati \\
6.Sunan Gunung Jati & 6. Sunan Drajad & 6. Sunan Drajad \\
7. Sunan Giri & 7. Sunan Kalijaga & 7. Sunan Kalijaga \\
8. Sunan Drajad & 8. Raden Patah & 8. Sunan Muria \\
9.Sunan Kalijaga & 9. Fathullah Khan & 9. Sunan Pandanaran \\
\hline
\end{tabular}

Menyoroti Walisongo angkatan V, maka agen yang paling berperan dalam dakwah Islam masa ini adalah Sunan Ampel (1401 $1481 \mathrm{M}$ ) yang memiliki beberapa keunggulan baik dalam bidang pengajaran dan komunikasi. Terkait hal ini Masykur Arif menuliskan dalam bukunya bahwa ia sering mendatangi langsung objek dakwahnya baik dalam bentuk perorangan maupun kelompok dan menyampaikan dakwah melalui pidato atau melakukan pengajaran di beberapa pesantren yang sengaja didirikan. ${ }^{40}$ Di Jawa, Sunan Ampel terkenal sebagai seorang orator ulung. la pandai membuat aforisme-aforisme bahasa yang mudah diingat, salah satunya seperti jargon Moh Limo yang saat itu menjadi pegangan dasar pengaturan norma sosialnya. Dalam referensi yang lain, Sunan Ampel (1401-1481 M) bahkan digambarkan sebagai sosok yang pandai menaklukan hati para mad'uw sehingga sangat sulit untuk menolak ajakannya. Widji Sasono menyebutkan bahwa ia menyampaikan ajaran-ajaran Islam dan mampu membangun simpati pada Prabu Kertawijaya. Meskipun pada akhirnya penguasa Majapahit tersebut menolak masuk Islam, hal tersebut lebih dikarenakan

\footnotetext{
${ }^{40}$ Arif, Sejarah Lengkap Wali Sanga, 93.

${ }^{41}$ Widji Saksono, Mengislamkan Tanah Jawa dalam Masykur Arif, Sejarah Lengkap Wali Sanga, Dari Masa
}

adanya pertimbangan yang berkaitan dengan eksistensi dirinya sebagai raja simbol kebudayaan Hindu Jawa serta untuk meminimalkan gejolak sosial di masyarakat. ${ }^{41}$ Selain itu dalam dakwahnya Sunan Ampel (1401 - 1481 M) melakukan kaderisasi agen pendakwah kepada para keturunan raja dan bangsawan lokal Jawa pada masa itu dengan jalan menjadikan mereka murid pada pesantren yang ia dirikan. Sunan Giri (1442 - 1506 M), Sunan Gunung Jati (1448 - 1568 M), Sunan Kalijaga (1460 - 1513 M) dan Sunan Kudus (wafat 1550 M), adalah beberapa contoh bangsawan Jawa yang menjadi murid Sunan Ampel untuk kemudian menjadi "kepanjangan tangannya" sehingga Islam dengan cepat menyebar hingga ke daerah pelosok.

\section{2) Disorganisasi Kultur Hindu Syiwa di Jawa}

Secara teoretis perubahan sosial budaya dimulai dengan adanya kondisi disintegrasi pada budaya lama. Dalam kasus ini juga terdapat gejala-gejala memudarnya norma dan nilai Majapahit yang menjadi titik balik diterimanya Islam di Jawa pada abad tersebut. Daliman menyebutkan bahwa

Kecil, Dewasa, Hingga Akhir Hayatnya, Yogyakarta: Dipta, 2013, 90-91. 
Islam masuk di Indonesia pada abad ke-15 saat pusat peradaban Hindu Jawa mengalami krisis, khususnya pada saat di mana pusat kekuasaan Hindu Indonesia bagian timur yaitu Kerajaan Majapahit yang mulai menghadapi saat keruntuhannya. ${ }^{42}$ Lebih lanjut ia menambahkan bahwa meninggalnya Gadjah Mada pada 1364 dan tidak lama kemudian disusul dengan meninggalnya Raja Hayam Wuruk pada 1389 menjadi titik balik yang menggoncangkan kekuasaan Majapahit. Pusat peradaban Hindu ini menunjukkan kelemahankelemahan dan secara tidak langsung membuka jalan proses dakwah Islam hingga membentuk kekuasaan politik baru yaitu Kerajaan Demak Bintara. Adapun kekuatan Majapahit makin lama makin rapuh akibat pemberontakan dan perebutan kekuasaan di kalangan keluarga raja, yang puncaknya menimbulkan kekacauan lewat Perang Paregreg (1401 - 1406) dan sekaligus mengantarkan Majapahit kepada keruntuhannya. Gejala krisis budaya lama ini sebenarnya dimulai ketika proses pergantian tahta Majapahit sepeninggal Prabu Kertawijaya, di mana para keturunannya saling berebut menjadi raja karena merasa bahwa merekalah yang lebih berhak atas mahkota Majapahit. Hal ini disebabkan karena sifat superior sehingga merasa lebih unggul antara satu dengan yang lain. Adapun yang menjadi korban dalam hal ini adalah penduduk, karena terlibat perang sipil yang diakibatkan kuatnya hasrat berkuasa oleh para pewaris dan bangsawan kerajaan yang ingin saling menguasai satu dengan yang lain. Data menunjukkan hingga saat itu, kerajaan ini hampir kehilangan separuh lebih

42 A. Daliman, Islamisasi dan Perkembangan Kerajaan Islam di Indonesia, (Yogyakarta: Ombak, 2012), 73. 43 Ibid. penduduknya akibat perang saudara yang berkepanjangan..$^{43}$

Indikasi adanya kesadaran melemahnya budaya lama juga dirasakan oleh penguasa Majapahit kala itu sehingga mendorongnya untuk menerima ajaran Islam yang dibawa Sunan Ampel karena dipandang bisa memberikan solusi untuk menjawab masalah masyarakatnya. Adapun Sunyoto dalam memaparkan data sejarah bahwa akibat perang saudara, muncul keprihatinan Raja Brawijaya $V$ akan kekacauan di kerajaannya sehingga mendorongnya untuk mengirim putra mahkotanya (Raden Patah) ke Palembang yang telah lebih dulu terakulturasi Islam dikarenakan alasan lebih senang belajar ajaran sufi daripada Hindu Buddha. ${ }^{44}$ Selain itu Maharaja Majapahit tersebut juga memiliki kawan, kerabat, ajudan dan beberapa orang Istri dari Champa dan Cina yang beragama Islam. kedekatannya dengan kaum muslim disinyalir karena sang Raja telah menaruh perhatian yang besar terhadap ajaran agama Islam. ${ }^{45}$ Terkait dengan hal ini Masykur Arif juga menunjukkan data bahwa Prabu Brawijaya sangat senang dan kagum atas ajaran Sunan Ampel. Baginya Islam adalah agama yang mengajarkan budi pekerti yang mulia. Hal ini dilatarbelakangi kekacauan Majapahit dipandang sangat membutuhkan ajaran yang lebih menekankan pada aspek budi pekerti luhur dan manusiawi sebagaimana yang diajarkan oleh Sunan Ampel. Oleh karenanya Sunan Ampel tidak dilarang berdakwah di Kerajaan Majapahit bahkan diberi wilayah khusus untuk menjalankan dakwahnya, walaupun saat itu Raja enggan memeluk Islam dengan alasan

\footnotetext{
44 Sunyoto, Atlas Walisongo, 393.

45 Ibid., 104-105.
} 
ingin menjadi raja terakhir yang beragama Buddha. ${ }^{46}$ Bahkan akibat rasa simpatiknya terhadap Islam, Sri Prabu Kertawijaya (Brawijaya $\mathrm{V}$ ) memberi peluang bagi orangorang Islam termasuk untuk memegang jabatan penting di Majapahit. Dalam hal ini, Sunan Ampel yang merupakan kemenakan istri Raja diangkat sebagai Imam dan Adipati Surabaya yaitu Ampeldenta. ${ }^{47}$ Khususnya bagi Raden Rahmat, dengan menempati wilayah Ampel merupakan keberuntungan besar baginya untuk menyebarkan Islam dengan mudah. Sebab, Surabaya pada waktu itu merupakan pintu gerbang utama bagi Majapahit yang merupakan pelabuhan tempat singgah bagi orang-orang yang memiliki kepentingan keluar masuk kerajaan tersebut. Oleh karena itu, dakwah Islam yang semula berada di pelabuhan Gresik menjadi semakin menusuk ke jantung Majapahit melalui pelabuhan Surabaya setelah Raden Rahmat dapat dengan mudah memperoleh informasi tentang situasi Majapait dari para pedagang dan orang-orang Majapahit sendiri yang melewati pelabuhan tersebut. ${ }^{48}$

\section{3) Proses Pengadopsian Nilai Islam di Jawa Masa Awal}

Agen yang banyak berperan dalam diterimanya Islam di tanah Jawa adalah Sunan Ampel sebagai leader angkatan $\mathrm{V}$ termasuk menjadi penggagas dan inisiator pendirian kerajaan Demak Bintara sebagai simbol kekuasaan Islam pertama di Jawa. Oleh karenanya dalam pembahasan berikutnya akan difokuskan pada Sunan ini dan beberapa wali yang memiliki signifikansi besar dalam islamisasi masyarakat Jawa hingga pedalaman. Raden Rahmat atau yang lebih dikenal dengan nama Sunan Ampel

\footnotetext{
${ }^{46}$ Arif, Sejarah Lengkap Wali Sanga, 112.

${ }^{47}$ Sunyoto, Atlas Walisongo, 104-105.

${ }^{48}$ Arif, Sejarah Lengkap Wali Sanga, 88.
}

memiliki dua cara yang dilakukannya dalam rangka mengenkulturasi nilai Islam yaitu kepada sasaran awal dan masyarakat luas. Enkultuasi nilai Islam pada sasaran awal dapat diketahui berdasarkan atas data bahwa setelah diangkat menjadi Imam Masjid di Surabaya, langkah awal yang dilakukan dalam dakwahnya adalah melakukan kaderisasi agen lewat sistem mengakuisisi sistem pendidikan lama (dukuh) ke dalam format Islam. Pendidikan formal sebelum pesantren ini dijelaskan oleh Sunyoto bahwa terdapat kemiripankemiripan yang cukup banyak antara pendidikan di pesantren-pesantren tradisional muslim dengan pendidikan seorang wiku (calon pendeta Syiwa-Buddha) di tempat yang disebut dukuh, di mana aspek pengajarannya lebih ditekankan kepada aspek pembentukan watak dan budi pekerti. ${ }^{49}$

Di dalam dukuh diajarkan prinsip ketundukan siswa kepada guru dengan konsep gagasan guru bhakti yang mencakup tiga guru (triguru), yaitu guru rupa yaitu orang tua yang melahirkannya, guru pangajyan berarti orang yang mengajarkan pengetahuan ruhani, dan terakhir adalah raja sebagai guru wasesa. Khusus untuk guru pangajyan diberi gelar "susuhunan" yaitu orang yang berhak melakukan baiat (diksa). ${ }^{50}$ Adapun kata santri adalah sebutan murid yang diadaptasi dari istilah sasthri, bermakna orang-orang yang mempelajari sasthra (kitab suci). Dari mekanisme dukuh ini kemudian melahirkan tokoh-tokoh Walisongo dari kalangan pribumi seperti Raden Patah, Sunan Giri, Sunan Kalijaga, dan lain sebagainya. Bahkan salah satu murid

\footnotetext{
${ }^{49}$ Sunyoto, Atlas Walisongo, 422.

$50 \mathrm{lbid}$.
} 
Sunan Ampel yaitu Raden Patah menjadi penguasa Islam pertama di tanah Jawa yaitu kerajaan Demak Bintara. Terkait hal ini De Graaf memaparkan data bahwa seseorang dari Ampeldenta mengutus salah seorang muridnya untuk mendirikan permukiman Islam di daerah dekat Demak Bintara. ${ }^{51}$

Secara tinjauan efektivitas, penggunaan media dukuh ini bisa dikatakan memiliki kesesuaian dengan sasaran awal yang merupakan tokoh berpengaruh dari kalangan bangsawan Majapahit sebagai simbol budaya Hindu-Syiwa. Selain itu, nilai ajaran Islam tentang moral tasawuf memang sesuai jika disosialisasikan dengan menggunakan media pendidikan seperti sistem dukuh yang lebih familier pada saat itu. Apalagi sistem dukuh ini secara penyebaran hampir merata di setiap wilayah kekuasaan Majapahit. Oleh karenanya, masyarakat akan memiliki kemudahan akses dalam mempelajari Islam hingga ke daerah pedalaman.

Sedangkan terhadap masyarakat luas sunan Ampel banyak menggunakan asumsi dakwah bilhal dengan memberikan kemanfaatan yang dapat dirasakan oleh banyak kalangan. Salah satu contohnya adalah saat rombongan Sunan Ampel melalui Desa Krian, Wonokromo dan Kembang Kuning ia menyempatkan diri berdakwah kepada penduduk setempat yang dilaluinya. Dakwah yang pertama kali dilakukannya cukup unik yaitu membuat kerajinan berbentuk kipas yang terbuat dari akar tumbuh-tumbuhan tertentu yang dianyam bersama rotan. Kipas-kipas itu diberikan dengan cuma-cuma kepada para penduduk. Untuk

${ }^{51}$ H.J De Graaf \& TH.G.TH. Pigeaud, Kerajaan Islam Pertama di Jawa: Tinjauan Sejarah Politik Abad XV dan XVI, (Jakarta: Grafiti, 2003), 45. mendapatkannya, mereka cukup menyebutkan dua kalimat syahadat. ${ }^{52}$ Faktanya kipas ini sangat berguna karena mengandung obat untuk menyembuhkan penyakit tertentu di masyarakat kala itu. Khasiatnya muncul ketika akar-akar yang sudah dianyam menjadi kipas itu dicelupkan pada air, kemudian airnya diminum. Para warga merasa sangat senang terhadap kipas dari akar yang dianyam bersama rotan itu ternyata berdaya penyembuh bagi mereka yang terkena penyakit batuk dan demam. Di sisi lain, Sunan yang bertugas di daerah Ampeldenta ini menggunakan istilah setempat untuk menyosialisasikan nilai-nilai Islam yaitu aktivitas salat diubah menjadi sembahyang (asal kata Hindu sang hyang, yang berarti menyembah Tuhan/Allah), musala dibahasakan dengan langgar yang secara pengucapan hampir mirip dengan istilah sanggar bagi masyarakat Hindu. Sedangkan kata santri yang berarti pelajar dalam Islam memiliki kemiripan dengan diksi sasthri yang berarti kaum cendekiawan dalam bahasa Hindu.

Dalam hal berkomunikasi dengan masyarakat setempat Sunan Ampel menggunakan bahasa Jawa, walaupun bahasa Jawa-nya bercampur dengan cara pengucapan bahasa Arab. Dengan mempelajari tradisi setempat, ia bisa beradaptasi dan jika terdapat tradisi yang melenceng jauh dari agama Islam, ia melakukan perubahan. Perubahan tidak mungkin dilakukan jika sebelumnya tidak mengerti tradisi yang akan diubah. Ketika Sunan Ampel membangun tempat ibadah, ia tidak memberikan nama Arab pada tempat ibadah itu, seperti musala, melainkan

${ }^{52}$ Arif, Sejarah Lengkap Wali Sanga, 85. 
memberi nama langgar yang mirip dengan sanggar. Ketika menyembah Tuhan, ia juga tidak menggunakan bahasa Arab seperti salat, melainkan menyebutnya sembahyang yang berasal dari kata sembah dan hyang. Sunan Ampel juga terkenal sebagai orator ulung dalam menyampaikan dakwah dengan membuat jargon yang mudah diingat, salah satunya Moh Limo yang cukup terkenal, yang artinya tidak mau melakukan lima hal tercela yaitu Moh Maling (tidak mau mencuri), Moh Ngombe (tidak mau minum arak atau mabuk-mabukan), Moh Main (tidak mau berjudi), Moh Madon (tidak mau berzina atau main perempuan yang bukan istrinya) dan Moh Madat (tidak mau narkoba, seperti menghisab candu, ganja, dan lain-lain). ${ }^{53}$ Lima prinsip ini nyatanya telah berkembang menjadi pedoman hidup masyarakat meskipun hal tersebut merupakan penyimpangan dari tradisi hasil sinkretis Syiwa-Buddha dengan Kapitayan (sekte saktha dan bhairawa-tantra) yaitu upacara adat yang disebut pancamakara atau $\mathrm{Ma}$ lima meliputi mamsha (daging), matsya (ikan), madya (minuman keras), maithuna (bersetubuh), mudra (bersemadi).

Berkat strategi dakwahnya, pengikut Raden Rahmat menjadi makin banyak di tempat ini apalagi sejak ia berkenalan dengan Ki Wiryo Sarojo dan Ki Bang Kuning yang merupakan dua tokoh masyarakat di daerah ini. Raden Rahmat dengan karisma dan kemampuan dakwahnya bisa membuat kedua tokoh berikut keluarganya masuk Islam dan menjadi pengikutnya. Adanya kedua tokoh tersebut telah memudahkan untuk mengadakan pendekatan dengan

\footnotetext{
53 Ibid., 110

54 Ibid., hal 86

${ }^{55}$ Widji Saksono, Mengislamkan Tanah Jawa (coba cari buku aslinya?) dalam Masykur Arif, Sejarah Lengkap
}

masyarakat sekitarnya khususnya kepada mereka yang masih memegang teguh tradisi Hindu Jawa. ${ }^{54}$ Selain itu dalam hubungan sosial, Sunan Ampel banyak mengembangkan sikap ramah kepada orang lain, seperti berkata-kata luhur, budi bahasa yang menarik, baik hati dalam bergaul dengan orang lain, dan bersikap sangat menyenangkan. ${ }^{55}$ la memberi pengertian sedikit demi sedikit tentang pentingnya ajaran Islam dan tidak langsung melarang kebiasaan kepercayaan mereka. Sedikit demi sedikit, ajaran tauhid (Islam) yang di dalamnya terdapat prinsip keimanan kepada Tuhan Pencipta alam tanpa membuat sekutu bagi-Nya perlahan diperkenalkan. Dalam hal bermazhab, Raden Rahmat juga terkenal sangat demokratis terhadap perbedaan pemikiran. la mengembangkan sikap toleran dengan tidak mempersoalkan mazhab keyakinan orang lain yang berbeda dengannya. Toleransi bermazhab ini diberlakukan kepada siapa saja, tanpa terkecuali baik terhadap santrinya, para juru dakwah dari berbagai daerah bahkan kepada anaknya sendiri. ${ }^{56}$ Berkat toleransi inilah banyak kalangan yang menaruh simpati dan mengapresiasi dengan berdatangan ke pusat dakwah Raden Rahmat di Ampeldenta, Surabaya. Dalam hal ini Sunan Ampel mampu mengadaptasikan ajaran Islam sesuai dengan kondisi lingkungan masyarakat Jawa. Oleh karenanya, Islam mudah dimengerti dan diterima oleh masyarakat setelah ia tidak menggunakan strategi arabisasi, melainkan menginfiltrasikan nilai ajaran Islam dalam sebuat tradisi.

Wali Sanga, Dari Masa Kecil, Dewasa, Hingga Akhir Hayatnya, Dipta: Jogjakarta, 2013, 90-91.

${ }^{56}$ Arif, Sejarah Lengkap Wali Sanga, 88. 
Adapun panggilan sunan berasal dari kata suhu nan, artinya "guru besar" atau orang yang berilmu tinggi. Adapula yang mengartikan sunan sebagai "yang dijunjung tinggi" atau panutan masyarakat dengan nama lain susuhunan. Sementara itu, Ampel adalah nama daerah tempat tinggal sekaligus wilayah dakwahnya. Raden Rahman dengan gigih berdakwah dan membangun wilayah Ampeldenta dengan bernapaskan Islam, oleh karenanya ia mendapat gelar Sunan Ampel. Di sinilah ia mendirikan pusat dakwah Islam berbentuk pesantren yang sekaligus menjadi pusat dakwah. Lewat pesantren masyarakat diajarkan tetang akidah, syariat, dan akhlak mulia. Dengan ajaran dan pembawaan yang bijaksana banyak yang tertarik belajar di Pesantren Ampeldenta hingga pusat pendidikan Islam ini menjadi tenar di seluruh pelosok negeri dalam waktu yang relatif singkat. ${ }^{57}$

Metode dakwah bilhal kepada masyarakat luas juga diikuti oleh murid-murid Sunan Ampel yang juga mendirikan sentra-sentra dakwah di sepanjang Pulau Jawa. Beberapa di antaranya yang cukup tersohor adalah Sunan Bonang dan Sunan Kalijaga yang berdakwah dengan media kesenian Jawa khususnya wayang. Dalam rangka menarik minat publik terhadap kajian Islam, Sunan Bonang bersama sunan Kalijaga menggubah beberapa lakon pewayangan yang telah mendarah daging di masyarakat menjadi bernapaskan Islam, seperti lakon Petruk Jadi Raja dan Layang Kalimasada. Lebih lanjut Sunyoto menunjukkan bahwa pertunjukan wayang ala Wali dapat dengan mudah menarik perhatian masyarakat. Mereka terpesona dengan keindahan permainan

$57 \mathrm{lbid}$.

${ }^{58}$ Arif, Sejarah Lengkap Wali Sanga, 129-130. wayang yang pakem ceritanya sudah digubah dengan nilai Islam. Pun demikian dengan kelihaian dalang memainkan karakter lakon wayang, menjadikan masyarakat lebih mempercayai cerita Ramayana dan Mahabharata versi Wali daripada cerita aslinya. ${ }^{58}$ Contohnya seperti Sunan Kalijaga yang sering mengenalkan Islam kepada penduduk lewat kesenian yang sangat digemari oleh masyarakat pengikut kepercayaan agama lama. la terkenal memiliki keahlian dalam memainkan karakter tokoh pewayangan yang salah satunya lakon Dewa Ruci dan Bima yang merupakan analog perjalanan spiritual Sunan Kalijaga dengan titik tekan pada sifat sabar saat berhadapan dengan sosok mistis seperti Nabi Kidir.

Terkait dengan hal ini Purwadi menyebutkan bahwa Sunan Kalijaga dapat memadukan dakwah dengan seni budaya yang mengakar kuat di masyarakat seperti misalnya wayang, tembang, gamelan, ukir, dan batik. Dalam praktiknya ia menggubah beberapa tembang di antaranya dhandhanggula semarangan dengan paduan melodi Jawa dan Arab. ${ }^{59}$ Ketika menjadi dalang di berbagai daerah di Pulau Jawa bagian barat hingga timur dari wilayah Pajajaran hingga wilayah Majapahit, Sunan Kalijaga menggunakan berbagai nama samaran agar tidak terkesan sedang berdakwah. Selain itu Sunan Kalijaga juga berkeliling dari satu tempat ke tempat lain dan memanfaatkan pertunjukan barongan, tari topeng, dan menjadi dalang pantun serta dalang wayang. Masyarakat yang ingin mengadakan pertunjukan wayang Sunan Kalijaga tidak membayar dengan mata uang, namun cukup membaca dua kalimat

\footnotetext{
59 Purwadi, Dakwah Sunan Kalijaga, 99.
} 
syahadat sehingga Islam dapat berkembang pesat dengan cara demikian. ${ }^{60}$

Adapun dalam bukunya, Abdul Hadi menyebutkan bahwa Sunan Bonang adalah seorang musikus dan komponis terkemuka. Konon ia menciptakan beberapa komposisi tembang Jawa bernama "gendhing dharma" dengan ajaran sufistik menjadi roh yang mewarnainya. ${ }^{61}$ Prinsip gubahan lagunya berpatokan pada alunan bunyi musik tertentu yang apabila didengarkan menciptakan kesan dan nuansa kesakralan batin menuju ke alam kerohanian. Selain itu ia juga menambahkan instrumen baru yaitu bonang pada perangkat alat musik Jawa bernama gamelan. Alat musik ini sebenarnya berasal dari Champa dan menjadi hadiah pernikahan Brawijaya $\mathrm{V}$ dengan bibinya. Selain itu ia juga memperkenalkan instrumen lain yang berasal dari Arab dengan sebutan rebab pada gamelan di Kerajaan Hindu Jawa. Hingga sekarang rebab sangat dominan pada gamelan Jawa dan bahkan dijadikan sebagai "raja instrumen". Meski berasal dari tradisi yang sama namun hal ini tidak ditemukan pada gamelan Bali. Data lain menyebutkan bahwa masyarakat sangat terhibur dengan bunyi merdu dari alat musik bonang yang diciptakan oleh Sunan Bonang. Orang Jawa tidak hanya senang dengan suara bonang, tetapi juga gubahan lagu-lagu atau tembang-tembang ciptaannya yang dipandang sesuai mengikuti irama musik dari bonang itu sendiri. ${ }^{62}$ Saat banyak penduduk yang menaruh simpati dan ingin belajar menabuh bonang serta lagulagu gubahannya, maka saat itulah Sunan Bonang menyampaikan dakwahnya. Ajaran Islam juga dimasukkan dalam kesenian klasik berbentuk tulisan atau karya sastra Jawa.

\footnotetext{
60 Sunyoto, Atlas Walisongo, 267-268.

${ }^{61}$ Arif, Sejarah Lengkap Walisongo, 125-127,
}

Karya sastranya yang disebut suluk. Suluk memiliki arti menempuh jalan kesempurnaan batin atau jiwa dengan mengamalkan ajaran tasawuf atau tarekat. Terdapat cerita ajaran tasawuf dari Sunan Bonang yaitu tembang yang berjudul "tombo ati" yang paling populer bahkan hingga saat ini. Suluk tombo ati masih sering dibaca di pesantren, masjid, maupun langgar di desa-desa yang berfungsi sebagai syairdzikir yang lazimnya dibaca sambil menunggu momen dilaksanakannya salat berjamaah. Tembang tersebut berisi nasihat agar hati atau jiwa manusia selalu tenang, damai, dan tenteram. Jika jiwa yang sudah sakit tidak diberi penawar, maka akan dianggap berbahaya bagi pemiliknya. ${ }^{63}$

\section{4) Reorganisasi (Reintegrasi) Ajaran Islam Sufistik dalam Kebudayaan Jawa}

Konsep reorganisasi mengacu pada suatu proses pembentukan norma-norma dan nilai-nilai baru agar serasi dengan lembagalembaga kemasyarakatan yang telah mengalami perubahan. Dalam hal ini ajaran Islam sebagai nilai baru berfungsi sebagai acuan pembentukan norma sosial yang diterapkan dalam pranata sosial di masyarakat. Proses reorganisasi pada kasus dakwah Walisongo angkatan $\mathrm{V}$ ini dapat dilihat dari beberapa modikasi dan perubahan adat dan tradisi Jawa menjadi lebih bernapaskan Islam dalam berbagai sektor kehidupan masyarakatnya. Fase ini banyak dilakukan setelah kaderisasi agen pada sasaran awal hingga era berkuasanya Demak Bintara sebagai kerajaan Islam pertama di Jawa. Bentuk reorganisasi pertama, dikeluarkannya kebijakan kerajaan Demak yaitu mengembangkan beberapa dukuh ke berbagai pelosok desa di wilayah

62 Ibid.

${ }^{63}$ Arif, Sejarah Lengkap Wali Sanga, 136. 
Majapahit (thani) tidak hanya sebatas di pusat keraton seperti sebelumnya. Ajaran Islam disesuaikan dengan kebiasaan adat melalui lembaga-lembaga pendidikan lokal tersebut dan Hindu-Buddha dapat berkembang dengan cepat di tengah masyarakat. $^{64}$

Reorganisasi kedua, dapat dilihat pada sektor kesenian dan bahasa. Terkait dengan bidang bahasa, Ricklefs menjelaskan bahwa pertemuan dua budaya Islam dan Jawa tidak menjadi masalah yang besar karena istilahistilah lokal misalnya Tuhan, sembahyang, surga, dan jiwa sering dipakai oleh walisongo dan bukan istilah Arab. $^{65}$ Sedangkan kesenian asli yang menjadi perhatian para wali untuk dimasuki nilai-nilai Islam adalah wayang kulit. Perubahan norma-norma sosial dalam kesenian wayang dipatenkan ke dalam peraturan oleh Raden Patah selaku penguasa kerajaan Islam Demak Bintara yang menggantikan kerajaan Majapahit. Adapun bentuknya adalah mengubah dan sekaligus menyesuaikan epos Ramayana dan Mahabharata yang sangat digemari masyarakat saat itu dengan ajaran Islam. Dalam proses tersebut terjadi "dedewanisasi" menuju "humanisasi" dalam rangka menanamkan tauhid. Usaha "dedewanisasi" yang dilakukan dalam pengislaman epos Ramayana dan Mahabharata tecermin pada munculnya cerita-cerita yang berkait dengan kelemahan dan kekurangan dewa-dewa sebagai sembahan manusia. Adapun bentuk pelembagaan Islam dalam kesenian wayang dijelaskan sebagaimana tabel berikut: ${ }^{66}$

Tabel 2 - Ketetapan Sultan Demak tentang Pakem Cerita Wayang agar Tidak Bertentangan dengan Tauhid

\begin{tabular}{|c|c|}
\hline Pra-Islam & Pasca-Islam \\
\hline $\begin{array}{l}\text { Cerita tentang poliandri yang menyangkut tokoh } \\
\text { Drupadi sebagai istri kelima bersaudara Pandawa. }\end{array}$ & $\begin{array}{l}\text { Diubah menjadi cerita monogami dengan } \\
\text { menggambarkan tokoh Drupadi sebagai istri } \\
\text { Yudhistira, putra tertua Pandu. }\end{array}$ \\
\hline $\begin{array}{l}\text { Dewa-dewa yang merupakan tokoh sembahan } \\
\text { yang hidup di kahyangan. }\end{array}$ & $\begin{array}{l}\text { Dibikinkan susunan silsilah sebagai keturunan } \\
\text { Nabi Adam dari jalur Nabi Syits. }\end{array}$ \\
\hline Tokoh-tokoh idola dalam ajaran Kapitayan seperti & Dimunculkan sebagai Punakawan yang memiliki \\
\hline $\begin{array}{l}\text { Danghyang Semar, Kyai Petruk, Nala Gareng, dan } \\
\text { Bagong. }\end{array}$ & $\begin{array}{l}\text { kekuatan adikodrati yang mampu mengalahkan } \\
\text { dewa-dewa Hindu. }\end{array}$ \\
\hline $\begin{array}{l}\text { Azimat kerajaan Amarta yang kekuatan } \\
\text { adiduniawinya mengalahkan kekuatan dewa-dewa } \\
\text { yang disebut Jimat Kalimasodo. }\end{array}$ & $\begin{array}{l}\text { Dimaknai sebagai Layang Kalima-Sahada yang } \\
\text { berkaitan dengan persaksian keislaman dalam } \\
\text { wujud Dua Kalimat Syahadat. }\end{array}$ \\
\hline
\end{tabular}

Reorganisasi berikutnya ada pada aspek struktur stratifikasi sosial yang berbentuk modifikasi kelas sosial Jawa yang disesuaikan dengan nilai-nilai Islam. Sunyoto menjelaskan bahwa sejak Islam masuk di

64 Sunyoto, Atlas Walisongo, 449-450.

65 M.C. Ricklefs, Mengislamkan Jawa: Sejarah Islamisasi di Jawa dan Penentangnya dari 1930 sampai Sekarang, (Jakarta: PT. Serambi Ilmu Semesta, 2013), 30.
Jawa maka golongan kelas bawah seperti domba, kewel, dapur, dan sebagainya dinaikkan menjadi kelas menengah. Selain itu para petani, pengrajin (tukang), nelayan, dan pekerja lain ke dalam golongan waisya. ${ }^{67}$

\footnotetext{
66 Ibid., 179

67 Ibid., 409.
} 
Dalam kasus lain terdapat fakta bahwa Sunan Gresik telah membantu para bangsawan kerajaan untuk tidak meremehkan kelas sosial yang lebih rendah, dan mengangkat derajat tiap kasta pada era Majapahit pada posisi yang sama dalam interaksi sosial. ${ }^{68}$ Selain itu Islam juga mencoba mengangkat posisi ulama/guru muslim setara dengan tokoh-tokoh adat yang memiliki pengaruh dan kedudukan tinggi di masyarakat. Dalam hal ini sekalipun kata "ulama" dalam konsep sosial Islam menunjuk kepada suatu pengertian tentang orang "yang berilmu," namun demi menguatkan legitimasi pengaruh di masyarakat Jawa, maka kata tersebut cenderung dihubungkan dengan kekuatankekuatan gaib yang disebut "daya sakti" berbentuk karamah atau ma'unah. Dengan daya tersebut, para wali dianggap bisa mendatangkan berkah bagi orang-orang yang taat dan memuliakannya, pun sebaliknya akan mendatangkan laknat dan kutukan bagi orang yang merendahkannya.

Sedangkan dalam bidang sosial lain, bentuk reorganisasi Islam dalam lembaga sosial Jawa dapat dilihat dari adanya pengajaran dan pembiasaan masyarakat menerapkan ajaran Islam dalam kehidupan sehari-hari. Aktor yang paling berperan dalam proses ini adalah para wali yang selain memberikan contoh (uswah) juga sekaligus mengajarkan tata cara hidup yang islami. Adapun Sunyoto dalam bukunya menyebutkan bahwa terdapat tugas tokoh-tokoh Walisongo dalam mengubah dan menyesuaikan tatanan nilai-nilai dan sistem sosial budaya masyarakat. Adapun Sunan Ampel bertugas membuat norma dan aturan hidup yang

68 Arif, Sejarah Lengkap Wali Sanga, 33.

69 Primbon milik Prof. KH. R. Moh. Adnan dalam Agus Sunyoto, Atlas Walisongo: Buku Pertama yang islami lewat Kerajaan Demak. Sunan Giri bertanggung jawab pada tata pemerintahan di Jawa, merintis pembukaan jalan, mengatur perhitungan kalender siklus perubahan hari, bulan, tahun, dan windu. Sedangkan Sunan Gunung Jati di Cirebon mengajarkan tata cara berdoa, membaca mantra, dan membuka hutan. Dalam bidang seni, ada Sunan Bonang yang mengajarkan ilmu suluk, membuat gamelan dan memodifikasi iramanya. Ada pula Sunan Drajat yang mengajarkan cara membangun rumah, membuat alat transportasi seperti tandu dan joli, serta terkait peralatan hidup. Sunan Kudus memelopori rancangan pekerjaan peleburan, membuat keris, kerajinan emas, melengkapi peralatan pande besi, dan dalam bidang hukum ia bertugas membuat peraturan undang-undang hingga sistem peradilan yang diperuntukkan bagi orang Jawa. ${ }^{69}$

\section{5) Asimilasi Kebudayaan Islam di Tanah Jawa pada Abad V}

Jenis perubahan sosial budaya yang dilakukan Walisongo angkatan $\mathrm{V}$ ini bisa dikategorikan sebagai perubahan terencana (planned-change) khususnya oleh Sunan Ampel atau Raden Rahmat yang sedari awal membidik kalangan keraton dan bangsawan Jawa sebagai sasaran awalnya. Adapun pemilihan segmen dakwah, strategi akuisisi dukuh, dan modifikasi wayang menunjukkan adanya usaha-usaha yang disengaja untuk tujuan perubahan kebiasaan masyarakat Jawa agar sesuai dengan ajaran Islam. Hal ini dibuktikan dengan adanya kebijakan penempatan agen-agen hasil kaderisasinya pada sentra-sentra dakwah di sepanjang pantai utara Jawa sehingga penyebaran

Mengungkap Walisongo sebagai Fakta Sejarah, Depok: Pustama Iman, 2017, 160. 
Islam dapat dilakukan dengan masif hingga ke ujung timur dan barat pulau ini. Pun dengan kemasan pesan dakwah yang dibuatnya lebih banyak mengakomodir kebiasaan asli Jawa baik dalam hal berbahasa, kesenian wayang, hingga tradisi ritual Hindu-Buddha.

Bisa dikatakan bahwa pada saat itu, para agen dalam lembaga Walisongo tersebut telah memotori terjadinya bentuk asimilasi kebudayaan Hindu Jawa dengan nilai-nilai Islam Sufistik. Adapun secara konseptual asimilasi adalah suatu kondisi di mana saat terjadi hubungan yang intensif di antara dua kultur yang berinteraksi hingga terjadi perpaduan antara pemikiran dan sistem perilaku keduanya. Perpaduan tersebut menandakan bahwa telah terjadi perubahan dan penyesuaian pada masing-masing unsur budaya Jawa dan Islam. Interaksi yang bersifat intensif antara kelompok pedagang muslim dengan kelompok Hindu Jawa telah menghasilkan penyesuaian dari unsur budaya Islam Sufistik dan Majapahit itu sendiri. Dalam hal ini bentuk asimilasi pemikiran dapat ditunjukkan dengan adanya pemaknaan para Wali tokoh sufi dalam pola pikir Hindu Jawa. Saat itu konsep Walisongo maknai sebagai "Nawa Dewata" yaitu gagasan bahwa mereka adalah manusia keramat yang memiliki kemampuan adikodrati seperti tokoh-tokoh dewa Hindu yang tidak kasat mata. ${ }^{70}$ Selain itu juga terdapat konsep guru bhakti yang merupakan bentuk percampuran pemikiran antara Hindu Syiwa dan Islam Sufi. Berdasarkan data tersebut dapat dipahami bahwa dengan masuknya Islam Sufi ke tanah Jawa maka terdapat perubahan yang cukup signifikan pada tataran nilai lama yang menganggap bahwa raja/tokoh masyarakat adalah titisan dari sanghyang taya dan dewa-dewa Hindu berubah menjadi keyakinan bahwa mereka dan wali adalah perantara Allah di muka bumi. Dalam hal ini yang perlu digarisbawahi yang menunjukkan bentuk percampuran Islam-Jawa adalah masih dipertahankannya nilai mistis atas dasar ajaran politeis Kapitayan-Hindu. Kepercayaan lama hanya mengalami beberapa modifikasi pada bentuk kepercayaan politeis berubah menjadi monoteis Islam Sufistik. Gagasan baru yang ditawarkan sebagai pengganti penyembahan dewa-dewa Hindu adalah bahwa para wali memiliki karamah yang diyakini dapat mendatangkan berkah, baik saat sang wali masih hidup maupun sesudah mati. Sedangkan ulama lain yang punya maqam rohani di bawah wali memiliki kekuatan adikodrati yang disebut ma'unah.

Bentuk perpaduan budaya Islam Sufi dan Jawa nyatanya telah memenuhi prasyarat pertama terjadinya asimilasi. Selanjutnya usaha saling bergaul sebagai syarat kedua terjadi antara masyarakat Jawa dan agen budaya baru yang ditunjukkan dengan masuknya guru sufi dalam struktur kerajaan Hindu Majapahit baik lewat perkawinan campuran maupun pendidikan dengan konsep guru bhakti. Perubahan pola pendidikan dari dukuh kepada sistem "pesantren" oleh guru sufi menandakan adanya penyesuaian-penyesuaian antara nilai Islam tasawuf dengan perangkat kebudayaan Hindu Jawa masa itu. Sekalipun asimilasi ini awalnya terlihat dilakukan di pesantren-pesantren dan komunitaskomunitas masyarakat muslim di pesisir, namun dalam proses penyebaran hasil

70 Sunyoto, Atlas Walisongo, 147. 
asimilasi tersebut terdapat kecenderungan menggunakan institusi keraton sebagai sentral.

Adapun beberapa hal yang dapat dipahami terkait pola perubahan asimilatif Jawa Islam oleh Walisongo adalah, pertama, faktor penyebab perubahan budaya di Jawa. Berdasarkan data proses masuknya Islam di Jawa, setidaknya dapat ditarik kesimpulan bahwa terdapat dua penyebab perubahan sosial budaya yang terjadi. Pertama yaitu dari internal masyarakat adanya kesadaran akan kelemahan budaya lama sehingga memerlukan gagasan baru sebagai solusi atas permasalahan yang ada. Di atas telah dijelaskan bahwa terdapat masalah konflik internal yang cukup pelik di kerajaan Majapahit dan daerah kekuasaannya. Data menunjukkan bahwa akhirnya Raja Majapahit mengundang sunan Ampel atau yang biasa disebut Ali Rahmatullah untuk mengajar agama di Jawa. ${ }^{71} \mathrm{Hal}$ inilah yang kemudian menjadi titik balik diterimanya ajaran Islam sufistik sebagai bagian dari way of life baru di Jawa. Berdasarkan data tersebut terdapat indikasi penyimpangan norma budaya lama oleh generasi baru Majapahit karena pada salah satu literatur disebutkan bahwa pada akhir abad XV, kerajaan Majapahit terpecah-belah dan diikuti peperangan berebut kekuasaan dari beberapa kelompok yang mengaku sebagai keturunan Majapahit di berbagai kerajaan kecil yang saling berperang satu dengan yang lain. Hal ini mengakibatkan pusat-pusat pendidikan keagamaan lama mengalami kemunduran karena dukuh sebagi pusat kajian agama Syiwa-Buddha tidak terurus. ${ }^{72}$

71 Purwadi dan Enis Niken, Dakwah Walisongo: Penyebaran Islam Berbasis Kultural di Tanah Jawa, (Yogyakarta: Panji Pustaka Yogyakarta, 2007), 23.
Sedangkan dari eksternal, terdapat faktor penyebab berupa migrasi dan misi agen eksternal yang membawa nilai Islam sufistik, terbingkai dalam upaya-upaya dakwah yang tersistematis dalam rangka melakukan perubahan sosial di Jawa. Adapun Sunyoto berpendapat bahwa para ulama dan para bangsawan asal Champa khususnya Sunan Ampel di Surabaya, mampu melakukan asimilasi dan sinkretisasi nilai Islam dengan adat budaya dan tradisi keagamaan yang sudah ada di Nusantara. Menurutnya, kiprah walisongo dengan kebijaksanaankebijaksanaan dakwahnya dapat menyampaikan ajaran Islam kepada masyarakat melalui pendekatan bersifat sosio-kultural-religius. ${ }^{73}$

Kedua, faktor pendorong proses perubahan budaya di Jawa. Mengacu pada teori faktor pendorong suatu perubahan sosial budaya, dalam kasus Islamisasi Jawa oleh Walisongo angkatan $\mathrm{V}$ ini dapat dipahami bahwa hal yang menjadi pemicu yang mempermudah proses diterimanya nilai Islam adalah karena adanya kontak antara kebudayaan Jawa dengan budaya Islam sufistik yang dibawa para ulama Timur Tengah khususnya Raden Rahmat (Sunan Ampel). Selain itu juga disinyalir terdapat gejala keterbukaan dalam sistem stratifikasi sosial di Jawa saat itu yang ditunjukkan dengan adanya fakta sejarah bahwa setelah kedatangan Raden Rahmat dan Raden Ali Murtadho ke Jawa, Raden Rahmat diangkat menjadi imam masjid di Surabaya oleh Raja Majapahit dan dikenal sebagai Sunan Ampel, dan Raden Ali Murtadho diangkat menjadi Raja Pandhita di Gresik. Selain itu Sri Prabu Kertawijaya (Brawijaya V) juga memberi peluang bagi

\footnotetext{
72 Sunyoto, Atlas Walisongo, 170.

73 Ibid., 158-159.
} 
orang-orang Islam untuk memegang jabatan penting di Majapahit. Hal ini merupakan efek multiplier dari adanya faktor pendorong lainnya yaitu gejala kelemahan budaya lama yang dirasakan oleh kalangan keraton. Kekuatan Majapahit semakin rapuh akibat pemberontakan dan perebutan kekuasaan di kalangan keluarga raja-raja sendiri. Ketidakpuasan atas kondisi dan kiprah kerajaan induk (Majapahit) inilah yang pada akhirnya menjadi momentum yang dimanfaatkan oleh Raden Rahmat untuk menawarkan way of life selain Hindu untuk mencapai stabilitas sosial.

Namun selain dua hal di atas, ditemukan juga adanya faktor pendorong lain yang berperan dalam mempercepat perubahan sosial budaya Jawa menjadi lebih "islami" yaitu adanya tawaran produk/nilai yang memiliki kesamaan dengan kebiasaan Jawa saat itu. Dalam hal ini, terdapat data yang menyebutkan bahwa Walisongo dalam dakwahnya banyak menyamakan kemiripan antara ajaran Islam dengan satyabrata seperti yang menyangkut halal dan haramnya makanan dan minuman. Sunyoto menyebutkan data bahwa seorang wiku wajib menghindari minuman keras yang memabukkan seperti arak, nira, anggur, brem, dan ciu karena dianggap tidak suci (camah) atau menjijikkan. ${ }^{74}$ Selain itu dalam ajaran tasawuf yang disebarluaskan kepada masyarakat Jawa, gagasan yamabrata dan niyamabrata dapat disamakan dengan takhilli (usaha membersihkan diri dari nafsunafsu rendah) dan tahalli (menghiasi diri dengan sifat-sifat ilahi) dalam rangka memperoleh pencerahan dan mengetahui kebenaran sejati. Pun demikian, ajaran tasawuf dapat diterima masyarakat karena

74 Ibid., 424. ada anggapan umum bahwa prinsip ajaran Islam tidak berbeda jauh dengan Syiwa Buddha. Oleh karena kesamaan pesan inilah yang membentuk "persepsi" bagi sebagian kalangan masyarakat bahwa ajaran Islam yang dibawa oleh Walisongo dianggap "selaras" dan tidak bertentangan dengan adat tradisi Jawa itu sendiri sehingga tidak menimbulkan penolakan yang berarti atas pesan dakwah yang disosialisasikan pada mereka.

Temuan faktor pendorong berikutnya yang menyebabkan mudahnya proses islamisasi Jawa saat itu adalah adanya kemudahan akses bagi masyarakat untuk mempelajari nilai budaya baru yaitu Islam. Hal ini terbukti hingga akhir abad ke XV di sepanjang pantai utara Jawa telah berdiri sentra-sentra dakwah Islam yang secara tidak langsung menjadi ujung tombak meluasnya Islam hingga ke Nusantara. ${ }^{75}$ Pusat mengkaji Islam yang terkenal adalah Ampeldenta di wilayah Surabaya, kemudian di sebelah baratnya terdapat Giri Kedaton tempat kediaman Raden Paku (Sunan Giri), sepupu Sunan Ampel. Di sebelah barat Giri Kedaton terdapat sentra dakwah yang disebut Drajat tempat kediaman Raden Qasim (Sunan Drajat) yaitu putra Sunan Ampel. Bergeser ke baratnya terdapat sentra dakwah yang disebut Sendang Dhuwur tempat kediaman Raden Nur Rahmat, putra Abdul Qahar bin Syaikh Abdul Malik al-Bahdady, terhitung keponakan Syaikh Datuk Abdul Jalil (Siti Jenar) yang menikahi putra Syaikh Abdul Malik al-Bahdady. Sebelah baratnya terdapat sentra dakwah Islam yang disebut Tuban tempat kediaman Raden Mahdum Ibrahim (Sunan Bonang), putra Sunan Ampel. Di sebelah barat Tuban terdapat

\footnotetext{
75 Sunyoto, Atlas Walisongo, 403.
} 
sentra dakwah Islam Lasem tempat kediaman Nyai Ageng Maloka, putri sunan ampel yang dinikahi Pangeran Wiranagara (Adipati Lasem), murid sunan Ampel. Sebelah barat Lasem terdapat sentra dakwah Islam yang disebut Demak Bintara tempat kediaman Raden Patah, murid sekaligus menantu Sunan Ampel. Sebelah baratnya terdapat sentra dakwah yang disebut Sunan Kalijaga serta Cirebon tempat kediaman Raden Sahid (Sunan Kalijaga) dan Syarif Hidayat (Sunan Gunung Jati), keduanya adalah murid sunan Ampel. Bahkan belakangan, dari sentra-sentra dakwah lain ke wilayah pedalaman Jawa dan luar Jawa hingga ke Hitu Maluku.

\section{Kesimpulan}

Perubahan sosial budaya pada sistem sosial masyarakat dimulai dengan adanya kondisi disintegrasi pada kebiasaan lama. Dalam kasus ini juga terdapat gejala-gejala memudarnya nilai dan norma kerajaan Majapahit yang menjadi titik balik diterimanya Islam setelah berabad-abad lamanya. Proses pengadopsian nilai Islam pada masyarakat Jawa khususnya pada abad $\mathrm{XV}$ tidak lepas dari peran agen perubah budaya yang dalam hal ini dimotori oleh Sunan Ampel yang memiliki "nama pribumi" yaitu Raden Rahmat. Kiprahnya dakwahnya memang telah dimulai sejak angkatan II, namun nyatanya baru pada angkatan ke-V syiar Islam mencapai hasil optimal. Hal ini ditunjukkan saat dirinya berhasil menggagas pendirian kerajaan Islam Pertama di Tanah Jawa yaitu Demak Bintara yang sekaligus menandakan berakhirnya kekuasaan Hindu Majapahit.

Proses reorganisasi pada kasus dakwah walisongo angkatan $\mathrm{V}$ ini dapat dilihat dari beberapa modikasi dan perubahan adat dan tradisi Jawa menjadi lebih bernafaskan Islam dalam berbagai sektor kehidupan masyarakatnya. Fase ini banyak dilakukan setelah kaderisasi agen di sasaran awal hingga era berkuasanya Demak Bintara sebagai kerajaan Islam Pertama di Jawa. Bentuk reorganisasi pertama adalah dalam bidang pendidikan dengan melakukan modifikasi sistem pendidikan ala Hindu yang dikenal dengan istilah dukuh. Reorganisasi kedua dapat dilihat pada kesenian wayang yang diubah sedemikian rupa sesuai ajaran Islam. Reorganisasi berikutnya ada pada aspek struktur-stratifikasi sosial yaitu melakukan modifikasi kasta Hindu Jawa. Sedangkan bentuk reorganisasi Islam dalam lembaga sosial lain dapat dilihat dari adanya pengajaran dan pembiasaan masyarakat menerapkan ajaran Islam pada kehidupan sehari-hari. Aktor yang paling berperan dalam proses ini adalah para wali yang selain memberikan contoh (uswah) juga sekaligus mengajarkan tata cara hidup yang islami.

Adapun faktor penyebab perubahan budaya dari internal masyarakat adalah adanya krisis dari kebiasaan lama sehingga memerlukan gagasan baru sebagai solusi atas permasalahan yang ada. Sedangkan dari eksternal, terdapat faktor migrasi dan misi agen eksternal yang membawa nilai Islam sufistik yang melakukan upaya dakwah dalam rangka melakukan perubahan sosial di Jawa. Selain itu ada pula faktor pendorong yang menjadi pemicu untuk mempermudah proses diterimanya nilai Islam yaitu adanya kontak antara kebudayaan Jawa dengan budaya Islam sufistik yang dibawa para ulama Timur Tengah. Adanya fenomena open stratification bagi ulama Islam khususnya di Majapahit juga merupakan efek multiplier dari adanya faktor pendorong 
lainnya yaitu gejala kelemahan budaya lama yang dirasakan oleh kalangan keraton. Selain dua hal diatas, terdapat faktor lain yang berperan dalam mempercepat perubahan sosial yaitu adanya tawaran produk yang memiliki kesamaan dengan kebiasaan saat itu serta adanya kemudahan akses bagi masyarakat Jawa untuk mempelajari nilai budaya baru yaitu Islam.

Bisa dikatakan bahwa jenis perubahan sosial budaya yang dilakukan Walisongo angkatan $\mathrm{V}$ ini adalah perubahan terencana (plannedchange) yang sedari awal membidik kalangan keraton dan bangsawan Jawa untuk melakukan "kaderisasi agen." Dengan strategi tersebut para pelaku dakwah dalam lembaga Walisongo telah mencapai suatu bentuk asimilasi kebudayaan Hindu Jawa dengan nilai-nilai Islam Sufistik. Bentuk perpaduan budaya Islam Sufi dan Jawa nyatanya telah memenuhi prasyarat terjadinya asimilasi sehingga menyebabkan perubahan sosial yang cukup signifikan tanpa menimbulkan konflik yang berarti. Dengan ini hikmah yang dapat diambil bagi para pelaku dakwah salah satunya adalah dakwah antarbudaya bukanlah hal yang mustahil dilakukan selama memahami jalanjalan kesuksesan yang dicontohkan oleh Walisongo. Namun perlu digarisbawahi khususnya bagi para agent of change saat ini bahwa perlu sikap yang bijak dan proporsional dalam meneladani dakwah asimilatif oleh walisongo tersebut karena tiap jenis perubahan sosial memiliki konteks permasalahan yang berbeda sehingga tidak bisa asal mengadopsi tanpa memperhatikan konteks situasi saat ini.

\section{Bibliografi}

Abdullah, Rachmad. Walisongo: Gelora Dakwah dan Jihad di Tanah Jawa (1404-1482). Bandung: Al-Wafi Publishing, 2017.

Amrullah, Achmad. Dakwah Islam Dan Perubahan Sosial. Yogyakarta: Bidang Penerbitan PLP2M, 1985.

Arif, Masykur. Sejarah Lengkap Wali Sanga, Dari Masa Kecil, Dewasa, Hingga Akhir Hayatnya. Yogyakarta: Dipta, 2013.

Daliman, A. Islamisasi dan Perkembangan Kerajaan-Kerajaan Islam di Indonesia. Yogyakarta: Ombak, 2012.

De Graaf, H.J. dan TH.G.TH Pigeaud. Kerajaan Islam Pertama di Jawa: Tinjauan Sejarah Politik Abad XV dab XVI. Jakarta: Grafiti, 2003.

Fatkhan, Muh. "Dakwah Budaya Walisongo - Aplikasi Metode Dakwah Walisongo di Era Multikultural." Aplikasia, Jurnal Aplikasi ilmu-ilmu Agama, Vol. IV No. 2 (2003): 122-141. http://digilib.uin-suka.ac.id/id/eprint/8200

Hatmansyah. "Strategi dan Metode Dakwah Walisongo." Jurnal Al-Hiwar, Vol. 03 No. 05 (2015): 10-17. Doi: 10.18592/al-hiwar.v3i5.1193.

Hizbullah, Muhammad. "Dakwah Harakah, Radikalisme, dan Tantangannya di Indonesia." Misykat Al-Anwar: Jurnal Kajian Islam dan Masyarakat, Vol. 29 No. 2 (2018): 11-24. Doi:10.31904/ma.v29i2.2856 
Nawawi. "Dakwah dalam Masyarakat Multikultural." Jurnal Komunika, Vol. 6 No. 1 (2012).

Purwadi. Dakwah Sunan Kalijaga: Penyebaran Agama Islam di Jawa berbasis Kultural. Yogyakarta: Pustaka Pelajar, 2007.

Purwadi dan Enis Niken. Dakwah Walisongo: Penyebaran Islam Berbasis Kultural Di Tanah Jawa. Yogyakarta: Panji Pustaka Yogyakarta, 2007.

Ranjabar, Jacobus. Perubahan Sosial: Teori-teori dan Proses Perubahan Sosial serta Teori Pembangunan. Bandung: Alfabeta, 2017.

Ricklefs, M.C. Mengislamkan Jawa: Sejarah Islamisasi di Jawa dan Penentangnya dari 1930 sampai Sekarang. Jakarta: PT. Serambi Ilmu Semesta, 2013.

Rosidi. "Dakwah Multikultural di Indonesia: Studi Pemikiran dan Gerakan Dakwah Abdurrahman Wahid." Jurnal Analisis: Jurnal Studi Keislaman, Vol. 13 No. 2 (2013): 481-500. Doi: 10.24042/ajsk.v13i2.708

Saksono, Widji. Mengislamkan tanah Jawa dalam Masykur Arif, Sejarah lengkap walisanga, dari masa kecil, dewasa, hingga akhir hayatnya. Dipta: Jogjakarta, 2013.

Sodikin, Ali. Antropologi Al-Quran: Model Dialektika Wahyu \& Budaya. Yogyakarta: Ar-Ruzz Media, 2013.

Soekanto, Soerjono. Sosiologi Suatu Pengantar. Jakarta: PT. Raja Grafindo Persada, 2007.

Suparjo. "Islam dan Budaya: Strategi Kultural Walisongo dalam Membangun Masyarakat Muslim Indonesia." Jurnal Komunika, Vol. 2 No. 2 (2008): 178-193.

Sunyoto, Agus. Atlas Walisongo: Buku Pertama yang Mengungkap Walisongo sebagai Fakta Sejarah. Depok: Pustama Iman, 2017.

Tajuddin, Yuliatun. "Walisongo dalam Strategi Komunikasi Dakwah." ADDIN, Vol. 8 No. 2 (2014): 367-390. Doi: 10.21043/addin.v8i2.602 